\title{
Skeletal Dose Estimation of the Patient Administered Ytterbium-169 Citrate for Tumor Diagnosis ${ }^{\dagger}$
}

\author{
Ikuro ANZAI, Masanori KANNO*, Hirohiko TOBARI* \\ and Tomomitsu HIGASHI* \\ Department of Radiological Health, Faculty of Medicine, \\ University of Tokyo, Tokyo, Japan \\ *Department of Radiology, Kanagawa Dental College, \\ 82, Inaoka-cho, Yokosuka-shi, Kanagawa, Japan \\ Received November 5, 1973
}

\begin{abstract}
Ytterbium-169 citrate has recently been put into medical use for external imaging of tumor tissues. The skeletal absorbed dose received by the patient was estimated in accordance with the MIRD Committee method. 500 micro-curie intravenous injection proved to result in 13 rads in skeleton, with the most important contribution of the internal conversion electrons emitted in the electron capture decaying process of the nuclide. The contribution of the penetrating radiations originating in other organs was found to be negligibly small. The average total body dose was approximately 2 rads.
\end{abstract}

\section{Introduction}

Ytterbium-169 citrate has been introduced recently as a possibly useful radioactive agent for external imaging of the tumor tissues. Ytterbium-169 was first utilised by F. Hosain (1968) for the purpose of brain scanning, cisternography and the measurement of glomerular clearance, chemical form being Yb-DTPA ${ }^{1}$. In 1972, K. Hisada, et al. experimented in applying the nuclide as a form of citrate compound for the tumor diagnosis ${ }^{2}$. It has been noticed, however, that ytterbium rapidly localizes in the whole skeleton $^{2) \sim 4)}$ and that the patient dose level becomes significant because of the relatively high radiosensitivity of the tissues in bone ${ }^{5), 6)}$.

\section{Experiments}

The authors performed a series of experiments to obtain information regarding excretion and deposition of the agent. $0.1 \mathrm{~m} l$ of Yb-169 citrate solution was injected intraperitoneally to ddN strain female adult mice, the administered radioactivity being 0.5 microcurie per gram. Fecal and urinary excretion of $\mathrm{Yb}-169$ were observed over ten days. The measurement of radioactivity was carried out with an $\mathrm{NaI}(\mathrm{Tl})$ scintillation counter. Line A of Fig. 1 is the whole body retention curve thus obtained, which can well be expressed by the following mathematical function;

$$
R=49 \cdot \exp \left(-\frac{0.693}{0.29} t\right)+51 \cdot \exp \left(-\frac{0.693}{800} t\right)
$$

where $R$ is the whole body retention in percent and $t$ is the time after administration in days. Equation (1) discloses that the biological half-life of $\mathrm{Yb}$-citrate immediately after intraperitoneal injection is about seven hours ( 0.29 days) and that approximately fifty percent of the radioactivity remains in the body with a long biological half-life ( 800 days). Curve $B$ in the same graph shows the result reported by A. Ando, et al., which is the retention of $\mathrm{Yb}-169$ citrate intravenously injected into a rat $^{2}$. The biological half-life in the slow phase was announced to be 60 days, far shorter than the result

$\dagger$ This research was partially sponsored by a grant from Japan Ministry of Education. 


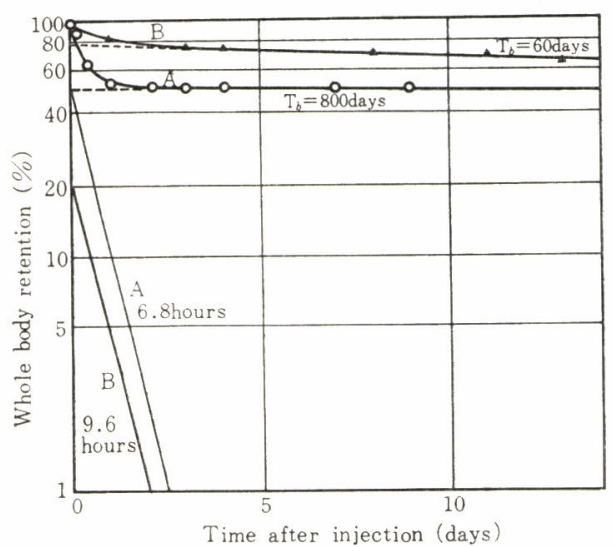

Fig. 1 Whole body retention curve of Yb-169 citrate.

A: mouse, intraperitoneal in jection (by present authors)

$B$ : rat, intravenous injection (by $\mathrm{A}$. Ando and K. Hisada)

given in the present investigation. The ICRP Publication 2 gave a value of 645 days as a biological half-life of ytterbium.

The authors attempted to make whole body autoradiogramsiwith a view to obtaining the information on distribution of the agent in the body. Fig. 2 is a typical example of the autoradiograms of a rat, which visualized a high level of deposition in the whole skeleton and liver. The scinticamera images of a rat that was injected Yb-169 citrate intraperitoneally also demonstrated a remarkable extent of deposition in the total skeleton (Fig. 3). Fig. 4 is a scintigram of a patient who was administered Yb-169 citrate for tumor diagnosis, also showing a considerably homogeneous deposition in bone. Table 1 is the experimental results on the concentrations in several important organs that were obtained from the scintillation counting of the organs of experimental mice sacrificed on the 14 th day after administration. The numerical values shown are the percentages of deposited activity per gram wet tissue to the total amount injected.

\section{Dose Calculation}

The absorbed skeletal dose* (rad) is principally reckoned by the following formula ;

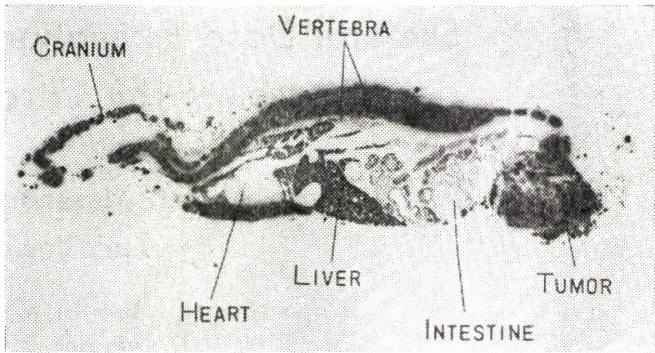

Fig. 2 An autoradiogram of a rat after intraperitoneal injection of ${ }^{169} \mathrm{Yb}$ citrate.

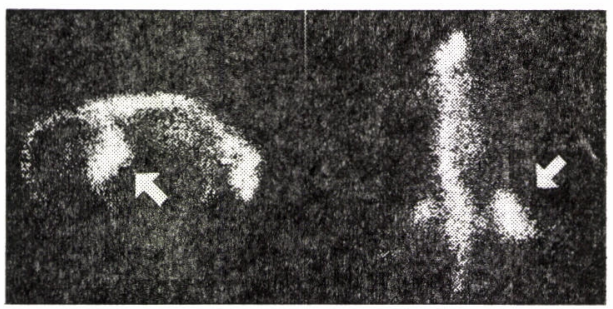

Fig. 3 Scinticamera images of a rat after intraperitoneal injection of ${ }^{169} \mathrm{Yb}$ citrate. (Arrows indicate the position of tumor.)

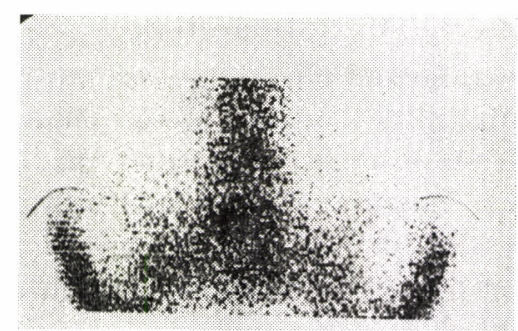

Fig. 4 A scintigram of lumbar vertebrae and pelvis of a patient after intravenous injection of ${ }^{169} \mathrm{Yb}$-citrate for tumor diagnosis.

Table 1 Concentrations of $\mathrm{Yb}-169$ in several organs

\begin{tabular}{l|c}
\hline Organ & \% per gram \\
\hline Bone & 8.21 \\
Liver & 3.93 \\
Kidney & 1.74 \\
Spleen & 1.02 \\
Stomach & 0.81 \\
Intestine & 0.53 \\
\hline
\end{tabular}

* The term "absorbed dose" is applied here in its conventional sense, not in the renewed and restricted meaning recommended by the ICRU in $1971^{(1), 8)}$. 


$$
\begin{aligned}
& D= \\
& \int_{0}^{\tau} \frac{q \cdot f \cdot\left(3.7 \times 10^{4}\right) \cdot\left(8.64 \times 10^{4}\right) \cdot E_{s-s} \cdot\left(1.60 \times 10^{-6}\right)}{100 \cdot m} \\
& \quad \cdot \exp \left(-\frac{0.693}{T_{\text {eff }}} t\right) \cdot d t \\
&
\end{aligned}
$$

where

$D$ : skeletal absorbed dose (rad)

$q$ : total radioactivity administered (microcurie)

$f$ : initial deposition in the total skeleton

$3.7 \times 10^{4}$ : number of disintegrations per microcurie

$8.64 \times 10^{4}$ : number of seconds per day

$E_{s-s}$ : energy per disintegration (MeV) absorbed in the total skeleton when the radionuclide is distributed homogeneously in the skeleton

$1.60 \times 10^{-6}$ : ergs per $\mathrm{MeV}$

100: absorbed energy (erg) per rad

$m$ : mass of the total skeleton (g)

$T_{\text {eff }}$ : eflective half-life (day)

$\tau:$ period of time for which the dose should be integrated (day).

Integrating,

$$
D=73.8 \cdot \frac{q \cdot f \cdot E_{s-s} \cdot T_{\text {eff }}}{m} \cdot\left(1-\exp \left(-\frac{0.693}{T_{\text {eff }}} \tau\right)\right)
$$

(1) $E_{s-s}$

The Medical Internal Radiation Dose Committee (MIRD Committee) of the Society of Nuclear Medicine developed an advanced method of evaluating the internally absorbed photon energy in the organ ${ }^{9)}$. In 1959, the ICRP recommended on the permissible dose for internal radiation, in which the Commission proposed a basic assumption for internal dose calculation that the shape of the organ can approximately be expressed by spherical model with an effective radius characteristic of each organ ${ }^{5}$. This assumption, however, is not always valid and often brings error in dose calculation to a considerable extent. The MIRD Committee, with due regard to the increasing importance of patient's dose evaluation with more exactitude, exploited a much progressed method for the purpose, and published a series of MIRD pamphlets for general use.

If the nuclear data on the radionuclide under consideration are available in the MIRD pamphlet, the dose calculation can be carried out with less complexity. But, concerning with the unfamiliar radionuclide such as Yb-169, one has to compute the necessary parameters in accordance with the method guided in the MIRD pamphlet No. 4.

Yb-169 decays by electron capture, the physical half-life of which is 31 days. Gamma rays and internal conversion electrons are emitted in the nuclear transition process of excited Tm-169 down to the ground state, and characteristic $X$ rays and Auger electrons are subsequently radiated in the atomic stabilization stage. The authors computed the nuclear parameters of Yb-169 by the procedure conforming to the MIRD Committee method, and collated the results with the calculated values which were personally offered by C. Holoway (ORNL) ${ }^{10)}$. Table 2 is the data thus obtained, where the absorbed energies per decay are listed up for gamma rays, characteristic $X$ rays, internal conversion electrons and Auger electrons respectively. The total absorbed energy per disintegration is proved to be $0.204 \mathrm{MeV}$. Apparently the internal conversion electrons have the most important contribution to the dose.

Table 2 Energy per disintegration ( $\mathrm{MeV}$ ) absorbed in the total skeleton when the radionuclide is distributed homogeneously in the skeleton

\begin{tabular}{l|c|c}
\hline \multicolumn{1}{c|}{ Radiations } & MeV/decay & Percent \\
\hline Gamma rays & 0.0311 & 15 \\
K-, L- X rays & 0.0404 & 20 \\
$\begin{array}{l}\text { Internal conversion } \\
\text { electrons }\end{array}$ & 0.1072 & 53 \\
Auger electrons & 0.0253 & 12 \\
\hline \multicolumn{1}{c|}{ Total } & 0.2040 & 100 \\
\hline
\end{tabular}

(2) $m$

In the MIRD pamphlet No. 5 the mass of the total skeleton is assumed to be 10,091 
gram $(\fallingdotseq 10 \mathrm{~kg})$ for adult human phantom, the total body mass of which is approximately $70 \mathrm{~kg}(70,036 \mathrm{~g})$. The value should be decreased or increased proportionally when the actual body weight of the patient differs from $70 \mathrm{~kg}$.

(3) $T_{\text {eff }}$

As stated in the previous paragraph, experiments in the present study unfolded 800 days of biological half-life as to the excretion from the total body, but the data are not directly available in connection with the value of $T_{\text {eff }}$ for skeleton. With respect to the excretion rate from the skeleton, however, the biological half-life can pertinently be taken as long as that for the total body, which leads $T_{\text {eff }}=30$ days. The reasons for this presumption lie in the following two points; (i) Excretion from the skeleton is thought to be the rate-determining process in the slow phase shown in Fig. 1. (ii) The ICRP Publication 2 gave a value of 1000 days for the biological halflife of ytterbium deposited in bone.

(4) $f$

The value of initial deposition fraction $f$ obtained in the present study is not so suggestive for the purpose of evaluating the absorbed skeletal dose of the patient intravenously administered Yb-169 citrate, because the agent was injected intraperitoneally in this research. The value of $f$ can be estimated by the following formula;

$$
f=\frac{c}{100} \cdot w \cdot b
$$

where $\quad c$ : concentration of $\mathrm{Yb}-169$ in bone (percent deposition per unit gram of bone)

$w$ : body weight ( $\mathrm{g}$ )

$b$ : fraction of the mass of skeleton to that of the total body.

The values for these parameters for rats with Yoshida sarcoma can be taken as $c=$ $2.5, w=160$ and $b=0.10^{11}$, which results in $f=0.40$. But the values are known to vary in the wide range, and the estimate obtained above can never be understood as fully exact. In the ICRP Publication 2, the fraction transported into bone from blood stream is reported to be $58 \%$, i.e. $f=0.58$. This value will be adopted here for dose calculation.

Substituting the above values for the parameters in the formula (3), the absorbed skeletal dose $D$ (rad) is estimated to be as graphically presented in Fig. 5. Approximately $90 \%$ of the accumulated dose is given in the first 100 days. In case that 500 microcurie is to be intravenously administered as was actually done, the total skeletal dose, or the skeletal dose commitment, turns out to be about 13 rads.

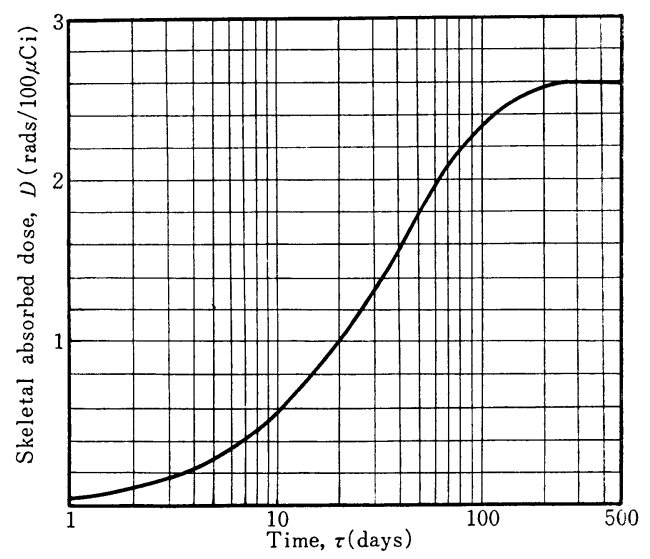

Fig. 5 Skeletal absorbed dose (rad) as a function of time (days).

The contribution to the skeletal dose of the penetrating radiations emitted from Yb-169 deposited in liver can be evaluated by substituting necessary values in the formula (3). The electron components emitted in liver can safely be assumed not to have any contribution to the skeletal dose, and the fraction of photon energies absorbed in bone can be quoted from the MIRD pamphlet No.5. Effective absorbed energy per decay thus calculated is $0.0159 \mathrm{MeV}$, approximately $7.8 \%$ of $E_{s-s}$. The value of $f$ for liver is missing in the ICRP reports, and it was guessed to be around 0.03-0.04 from the experimental results reported by Hisada, et al. and the present authors. The biological half-life of Yb-169 regarding the excretion from liver is not known accurately, but it is supposed to be fairly long, 
judging from the biological half-life of other lanthanide elements in liver. If the effective half-life is $\mathbf{3 0}$ days just as long as that for excretion from total skeleton, the absorbed skeletal dose brought by the penetrating radiations originating in liver is 0.05-0.07 rads for 500 microcurie injection, which is only a small percentage (0.4-0.5\%) of the skeletal dose given by $\mathrm{Yb}-169$ deposited in the total skeleton.

The average absorbed dose in the total body can be estimated by analogous procedure, which gives a value of 2.1 rads for 500 microcurie administration according to the data obtained in the present inquiry. Applying the values announced by Hisada, et al. ${ }^{2)}$, the dose comes out to be 2.3 rads.

\section{Conclusion}

The skeletal dose of the patient administered Yb-169 citrate for tumor diagnosis was estimated. 500 microcurie intravenous injection turned out to result in $13 \mathrm{rads}$ in skeleton, with the most important contribution of the internal conversion electrons. The contribution to the skeletal dose of the penetrating radiations emitted by $\mathrm{Yb}$ 169 deposited in other organs was found to be negligibly small. The average whole- body absorbed dose was approximately 2 rads.

\section{Acknowledgements}

The authors express their thanks to $\mathrm{Mr}$. Kunio Kawai of Tokyo College of Pharmacy for much of the work in making autoradiograms.

\section{References}

1) F. Hosain, et al.: Radiology, 91, 1193 (1968)

2) A. Ando and K. Hisada: Radioisotopes, 21, 549 (1972)

3) T. Higashi, et al.: Jap. J. Nucl. Med., 10, (1973)

4) T. Higashi, et al.: Jap. J. Clinical Radiology, 18, 188 (1973)

5) ICRP Publication 2 (1959)

6) ICRP Publication 11 (1967)

7) ICRU Report 19 (1971)

8) J. Neufeld: Health Physics, 24, 101 (1973)

9) MIRD Pamphlet Nos. 1 6

10) Clayton Holoway (Information Center for Internal Exposure, Oak Ridge National Laboratory): personal communication

11) A. Ando and K. Hisada: Radioisotopes, 21, 648 (1972)

\title{
要 旨
}

\section{腫瘍診断のためのクエン酸- ${ }^{169} \mathrm{Yb}$ 投与に伴う患者の骨線量の評価}

\author{
安斎育郎, 閑野政則*, 戸張宏彦*, 東 与光* \\ 東京大学医学部放射線健康管理学教室, *神奈川歯科大学放射線学教室
}

\begin{abstract}
近年，腫瘍診断を目的として導入されつつあるクェン酸- ${ }^{169} \mathrm{Yb}$ の患者への投与に伴 5 骨線 量の 評価を MIRD 法によって行なった。 ${ }^{169} \mathrm{Yb} 500 \mu \mathrm{Ci}$ の静注によって, 約 $13 \mathrm{rad}$ の骨線量が与兄 られるが，線量への寄与は，電子捕獲崩壊に付随して放出される内部変換電子が最も大きい。肝に 沈着する ${ }^{169} \mathrm{Yb}$ からの骨線量への笴与は $0.5 \%$ 程度であり，また $500 \mu \mathrm{Ci}$ 投与の場合の全身の平均

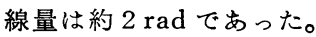

